\title{
INOVASI PENDAMPINGAN PEMBERIAN ASI PADA IBU PASCASALIN MENINGKATKAN PENGETAHUAN, SIKAP DAN PERILAKU IBU MENYUSUI
}

\author{
Deswani, Yuli Mulyanti \\ Poltekkes Kemenkes Jakarta III \\ Email:desika_64@yahoo.co.id
}

\begin{abstract}
Mentoring Innovations can be counseling to improve knowledge, attitude and behavior of the mother in giving BREAST MILK to the baby on the mother under labor. The purpose of the research was to identify the influence of breast feeding on mentoring Innovations mother amid labor against the success of the knowledge, attitude and behavior of the mother in the exclusive breast feeding. Design research is quasi experiment with pre-and post test of nonequivalent control group design. Sampling techniques with accidental sampling consisting of 38 respondents to the intervention group and the control group respondents 30, analysis by using different test and analysis of multivariate regression with bivariat and linear. The results showed that respondents who received the intervention, the results showed that respondents who received the intervention, there is an increase in the score of knowledge amounted to 2.514 with value $t=6.970$, an increase in score value 2.353 attitude $t=13.179$, and an increase in the score by 1.324 skills value $t=8.043$. The most dominant factor influencing the behavior of mothers in breastfeeding is support the husband. It was concluded that there was significant influence innovation program intervention mentoring mom breast feeding post childbirth on p-value of 0.000 to increased score of knowledge, attitudes and skills of respondents.
\end{abstract}

Keywords: innovation, mentoring, post delivery

\begin{abstract}
ABSTRAK
Inovasi pendampingan pemberian ASI dapat berupa konseling untuk meningkatkan pengetahuan, sikap dan perilaku ibu dalam memberikan ASI ke bayi pada ibu paska persalinan. Tujuan penelitian adalah untuk mengidentifikasi pengaruh Inovasi pendampingan pemberian ASI pada ibu paska persalinan terhadap keberhasilan pengetahuan, sikap dan perilaku ibu dalam pemberian ASI eksklusif. Desain penelitian adalah kuasi eksperimen dengan pre dan post test non-equivalent control group design. Tehnik pengambilan sampel dengan accidental sampling yang terdiri dari 38 responden kelompok intervensi dan 30 responden kelompok kontrol, Analisis data dengan menggunakan uji beda dan analisis bivariat dan multivariat dengan regresi linear. Hasil penelitian menunjukkan bahwa pada responden yang mendapatkan intervensi terdapat peningkatan skor pengetahuan sebesar 2,514 dengan nilai $t=6,970$, peningkatan skor sikap 2,353 dengan nilai $t=13,179$, dan peningkatan skor ketrampilan 1,324 dengan nilai $t=8,043$. Faktor yang paling dominan mempengaruhi perilaku ibu dalam menyusui adalah dukungan suami. disimpulkan bahwa terdapat pengaruh signifikan intervensi program inovasi pendampingan pemberian ASI pada ibu paska persalinan pada p-value 0,000 terhadap peningkatan skor pengetahuan, sikap dan keterampilan responden.
\end{abstract}

Kata kunci: inovasi, pendampingan, paska persalinan 


\section{PENDAHULUAN}

Berdasarkan data Susenas (Survei Sosial Ekonomi Nasional) menunjukkan grafik ibu menyusui yang mengalami penurunan pada lima tahun terakhir ini mulai tahun 2006 adalah 64,1\%, tahun 2007 turun menjadi 62,2\%, tahun 2008 menjadi 56,2\% dan tahun 2010 ada 33,6 persen bayi umur 0-6 bulan yang mendapatkan ASI eksklusif. Riset Kesehatan Dasar (Riskesdas) 2010 menyebutkan, hanya 15,3 persen bayi umur kurang dari 6 bulan yang mendapat ASI eksklusif. Faktor yang menyebabkan pemberian ASI tidak optimal, antara lain karena faktor ibu sendiri, tenaga kesehatan, produsen susu formula dan penyelenggara pelayanan kesehatan.

Riskesdas (2007) mengelompokan pola menyusui menjadi tiga kategori, yaitu menyusui eksklusif, menyusui predominan, dan menyusui parsial sesuai definisi WHO (2004). Menyusui eksklulif adalah tidak memberikan makan atau minuman lain, termasuk air putih selama menyusui (kecuali obat-obatan dan vitamin atau mineral tetes; ASI perah juga diperbolehkan. Menyususi ekslusif adalah tidak memberi bayi makanan atau minuman lain, termasuk air putih, selain menyusu kecuali obat-obatan dan vitamin atau mineral tetes. Asi perah juga diperbolehkan (bayi masih disusui selama
24 jam terakhir bayi hanya disusui, tidak diberi makanan selain ASI). Menyusui predominan adalah menyusui bayi tetapi pernah memberikan sedikit air atau minuman berbasis air, misalnya teh, sebagai makanan/minuman prelakteal sebelum ASI keluar (bayi masih disusui selama 24 jam terakhir bayi hanya disusui), sejak lahir tidak pernah medapatkan makanan atau minuman kecuali minuman berbasis air yaitu air putih atau air teh. Menyusui parsial adalah menyusui bayi serta diberikan makanan buatan selain ASI, baik susu formula, bubur atau makanan lainnya sebelum bayi berumur enam bulan. Baik diberikan secara kontinyu maupun diberikan sebagai makanan prelakteal. (bayi masih disusui, pernah diberikan makanan prelakteal selain makanan atau minuman berbasis air seperti susu formula, biskuit, bubur, nasi lembek pisang atau makan lain.

Presentasi pola menyusui pada bayi umur 0 - 1 bulan adalah 39,8 \% untuk menyusu ekslusif 5,1 \% menyususi predominan 51\% menyusui parsial. Presentasi menyusui eksklusif semakin menurun dengan meninggkatnya kelompok umur bayi. Bayi yang berumur 5 bulan menyusui ekslusif hanya 15,3\%, menyusui parsial 83,2 \%. Kegagalan dalam memberikan ASI secara eksklusif tersering terjadi pada 
bayi usia $<28$ hari, karena pada periode ini adalah perode adaptasi bagi ibu dan bayi. Cakupan pemberian ASI pada bayi 0-6 bulan berfluktuatif. Hasil survey demografi dan kesehatan Indonesia SDKI 2007, menunjukan cakupan ASI eksklusif bayi 06 bulan sebesar $32 \%$ yang menujukan kenaikan bermakna menjadi $42 \%$ pada tahun 2012. Di DKI Jakarta cakupan pemberian ASI Eksklusif 62,7 \% tahun 2012 diatas rata-rata nasional yaitu 54,3\%. Dari data Pusdatin 2013 didapatkan data estimasi absolute Bayi ASI Eksklusif dan tidak ASI dari 27.264 bayi, yang diberikan ASIE adalah 17.095 dan absolute tidak ASIE adalah 10.169 bayi.

Penelitian ini difokuskan pada pendampingan pada ibu paska persalinan dilakukan pendampingan, dukungan dan pemantauan pemberian ASI pada neonatus. Program Pendampingan ibu dalam menyusui ini ASI dirasakan penting untuk diteliti karena adanya kecenderungan ibu untuk gagal menyusui eksklusif dan turun menjadi menyusui predominan dan menyusui parsial pada 28 hari pertama kehidupan bayi (masa neonatus).

\section{METODE}

Penelitian ini menggunakan desain kuasi eksperimen semu dengan pendekatan pre dan post test accidental sampling control, yang bertujuan untuk melihat Pengaruh inovasi Program Pendampingan pemberian ASI pada ibu pasea nifas. Pada kelompok intervensi dan kontrol sebelum dilakukan perlakuan diberikan pretest terlebih dahulu yang bertujuan untuk menilai pengetahuan, sikap dan perilaku, kategori pemberian ASI setelah diberikan perlakuan pada kelompok intervensi dan kontrol dilakukan penilaian hasil melalui post test. Intervensi yang dilakukan adalah inovasi Program pendampingan pemberian ASI oleh penelti dengan memberikan edukasi tentang menyusui dengan berbagai tehnik, bervariasi, dengan menggunakan Booklet yang berjudul "Sayang Bayi beri ASI Eksklusif" dan video "konseling ASI" dan konseling, saat dilakukan kunjungan neonatus $(\mathrm{KN})$. Pendampingan dilakukan 2 kali, yaitu $\mathrm{KN} 1$ = kunjungan pertama (6 jam - hari ke-2) dan KN3 = kunjungan ketiga (hari ke 8 - hari ke 28).

Populasi pada penelitian ini adalah ibu post partum (melahirkan normal yang menyusui bayinya (bayi sehat) di Puskesmas kecamatan Jatinegara, Cipayung, Matraman dan Makasar.

Tehnik sampling yang digunakan dalam penelitian ini adalah tehnik non-probability sampling, metode accidental sampling. Penelitian dilakukan di Puskesmas Kecamatan Cipayung, mataraman, Jatinegara dan Makasar Jakarta Timur. Tempat penelitian dalam penelitian ini 
adalah Rumah bersalin Puskesmas Kecamatan Makasar dan Matraman untuk kelompok intervensi dan kelompok kontrol di Jatinegara, Cipayung, Tempat penelitian tersebut dipilih karena keempat Rumah Bersalin tersebut sudah melaksanakan kunjungan nifas dan neonatus sesuai standard dan sudah mempunyai Tim Kesehatan Tingkat RW.
Pengumpulan data penelitian ini dilakukan selama kurang lebih 6 minggu yaitu bulan Mei dan Juni 2016 di Rumah Bersalin Puskesmas Kecamatan Jatnegara, Cipayung, Makasar, dan Matraman Kuesioner sebanyak 78 eksemplar terisi, kuesioner yang terisi dilakukan analisis.

\section{HASIL DAN PEMBAHASAN}

Tabel 1. Analisis Kelompok intervensi dan Kontrol berdasarkan karakteristik di RB Puskesmas Kecamatan Jatinegara dan Cipayung, Makasar dan Matraman Tahun 2016

\begin{tabular}{|c|c|c|c|c|c|c|}
\hline \multirow{2}{*}{ No } & \multirow{2}{*}{ Variabel } & \multirow{2}{*}{ Kategori } & \multicolumn{2}{|c|}{ Intervensi } & \multicolumn{2}{|c|}{ Kontrol } \\
\hline & & & Jumlah & $\%$ & Jumlah & $\%$ \\
\hline \multirow[t]{4}{*}{1} & Tingkat & SD & 5 & 13,5 & 2 & 6,7 \\
\hline & Pendidikan Ibu & SMP & 8 & 21,6 & 7 & 23,3 \\
\hline & & SMA & 24 & 64,9 & 18 & 60 \\
\hline & & Perguruan Tinggi & - & - & 3 & 10 \\
\hline \multirow[t]{2}{*}{2} & Dukungan & SuamiKurang mendukung & 9 & 24,3 & 18 & 60 \\
\hline & Suami & Suami mendukung & 28 & 75,7 & 12 & 40 \\
\hline \multirow[t]{2}{*}{3} & Kategori & Menyusui Eksklusif & 28 & 75,7 & 22 & 73,3 \\
\hline & $\begin{array}{l}\text { Pemberian ASI } \\
\text { Eksklusif }\end{array}$ & Menyusui Prodominan & 9 & 24,3 & 8 & 26,7 \\
\hline
\end{tabular}

Pada penelitian ini sebagian besar responden berpendidikan menegah ke atas, pendidikan menyebabkan suatu dorongan terhadap seseorang untuk mencari tahu berbagai informasi yang mendukung pengetahuannya, sehingga pendidikan inilah yang berperan terhadap peningkatan ibu dalam menyusi (Azwar 2000). Kurangnya pengetahuan dan informasi pada masa sebelum melahirkan merupakan masalah yang dapat mempengaruhi ibu dalam memberikan ASi pada pada bayi. Berdasarkan hasil penelitian ini didapatkan bahwa dukungan suami pada ibu adalah hampir sebagian mempunyai dukungan suami yang baik dalam menyusui. Penelitian ini sejalan dengan Al-Akour, et al., (2010) dalam penelitiannya menyatakan bahwa faktor yang sangat berpengaruh terhadap keinginan ibu untuk menyusui adalah dukungan suami terhadap keluarga dalam pemberian ASI. Dukungan 
suami merupakan bagian dari mikrosistem seorang individu yaitu ibu menyusui. Mikrosistem ini merupakan salah satu komponen yang terdapat dalam teori Ramona T Mercer(2010) “ Maternal Role Attainment". Ibu akan melakukan peran yang baik dalam merawat bayinya jika mendapat dukungan yang baik juga dari keluarga terutama dari suaminya sebagai bapak dari bayinya. Stress yang dihadapi oleh seorang ibu ketika melahirkan dapat dicegah melalui peningkatan peran suami, sehingga peran perawatan bayi terutama dalam pemberian ASI untuk bertumbuh dan berkembang, dapat tercapai secara optimal melalui peran orang tuanya (ibu dan ayah) dengan bayinya (Russel,2006).

Roesli (2007) menyatakan bahwa suami dan keluarga dapat melakukan perannya yang baik pada ibu menyusui, yaitu dengan selalu memberikan dukungan secara moral dan melakukan bantuan-bantuan sederhana ketika menyusui, misalnya mendampingi ibu menyusui, menemani ibu untuk memerah ASI, dan lain-lain. Peran suami ini akan mendorong ibu untuk tetap menyusui bayinya, memberikan rasa percaya diri sehingga ibu tetap termotivasi menyusui dan membantu proses produksi ASI, menstabilkan emosi ibu paska persalinan.

Produksi ASI akan terus meningkat jika ibu mempunyai percaya diri yang tinggi untuk secara rutin menyusui bayinya, biarkan bayi menyusu dalam waktu yang diinginkan, lakukan pemberian posisi dan pelekatan yang benar, sehingga bayi akan terbiasa dengan mudah untuk menyusu pada ibunya. Banyak ibu mengatakan bahw bayinya tidak mendapatkan ASI yang cukup, karena bayi sering menangis dan tidak mau menyusu, produksi ASI ibu kurang, sehinga ibu memutuskan untuk menghentikan memberikan ASI dan memberikan bayinya susu formula (Departement Of Health Human dan Services, 2011; Depkes 2007). Penelitian Kemalasari (2008) berbeda dengan hasil penelitian ini dukungan dan partisipasi mempunyai proposi yang rendah terhadap ibu menyusui yang mempunyai dukungan suami yang kurang, dan mempunyai motivasi yang rendah dalam menyusui bayi. Hal ini disebabkan ibu tersebut tidak mempunyai percaya diri dalam pemberian ASI bagi bayinya. 
Tabel 2. Analisis Kelompok intervensi dan Kontrol berdasarkan umur ibu dan bayi di RB Puskesmas Kecamatan Jatinegara dan Cipayung, Makasar dan Matraman Tahun 2016 (Mei - Juni $2016 n=77$ responden)

\begin{tabular}{lllllllllll}
\hline \multirow{2}{*}{ Variabel } & \multicolumn{3}{l}{ Kelompok Intervensi } & \multicolumn{7}{c}{ Kelompok Kontrol } \\
& Mean & Median & SD & Min & Max & Mean & Media & SD & Min & Max \\
& & & & & & & $n$ & & & \\
\hline Usia Ibu & 29,84 & 30 & 5,85 & 19 & 40 & 26,27 & 25 & 6,18 & 16 & 40 \\
\hline Usia Bayi & 75,22 & 24 & 82,5 & 1 & 240 & 39,3 & 24 & 47,44 & 1 & 168 \\
& & & 3 & & & & & & & \\
\hline
\end{tabular}

Berdasarkan hasil penelitian ini didapatkan bahwa rata-rata usia ibu menyusui adalah 26.27, usia minimal adalah 16 Tahun dan usia maksimal adalah 40 Tahuan. Usia juga dapat dijadikan salah satu patokan untuk melihat tingkat kematangan secara biologis maupun psikologis pada seorang individu (Nursalam,2008). Penelitian Lestari, Indriati, dan Supriyono (2011) mengidentifikasi bahwa pada rentang usia $<20$ Tahun dianggap sebagai usia remaja, dimana pada usia ini ibu masih mempunyai kekhawatiran dalam perubahan penampilan ketika menyusui bayinya, ibu khawatir payudaranya akan menjadi turun, berat badan akan meningkat, sehingga memberikan susu formual menjadi pilihan ibu bagi bayinya, padahal anatomi payudara akan tetap berubah ketika ibu sedang menyusui ataupun tidak menyusui. Pada ibu yang berusia $<20$ tahun terdapat penurunan angka pemberian ASI, kondisi ini disebabkan adanya pengaruh budaya dan kepercayaan dalam masyarakat untuk melakukan penikahan muda (DPHSSPS, 2004). Hal ini sesuai dengan responden pada penelitian ini, yaitu ibu menyusui berasal dari wilayah Cipayung, dimana angka melahirkan usia dini cukup tinggi. Sebelum ibu menyusui bayinya persiapan secara psikologis merupakan hal yang sangat penting dilakukan. Persiapan psikologis ini harus dimulai saat ibu merencanakan kehamilan, pada masa kehamilan dan yang terpenting adalah ketika ibu sudah melahirkan. Persiapan ini penting dilakukan, karena dengan sikap dan keputusan ibu yang baik dan positif untuk menyusui anak berpengaruh terhadap kelangsungan pemberian ASI eksklusif pada bayinya (Hatfield, 2008). 
Tabel 3. Perbedaan pengetahuan, sikap dan perilaku ibu tentang pemberian ASI setelah diberikan Inovasi program pendampingan pemberian ASI pada ibu paska persalinan di RB Puskesmas Kecamatan Jatinegara, Cipayung, Matraman dan makasar (Mei - Juni $2016-\mathrm{N}=77$ responden)

\begin{tabular}{|c|c|c|c|c|c|c|}
\hline Variabel & Kelompok & Mean & SD & $95 \% \mathrm{CI}$ & $\mathrm{t}$ & $P$ value \\
\hline Pengetahuan ttg ASI & Kel. Intervensi & & & \multirow{3}{*}{$-3,245--1,782$} & \multirow{4}{*}{$-6,970$} & \multirow{3}{*}{0,000} \\
\hline \multirow[t]{7}{*}{ Eksklusif } & Sebelum & 8,65 & 1,602 & & & \\
\hline & Sesudah & 11,16 & 1,951 & & & \\
\hline & Selisih & $-2,514$ & & \multirow{5}{*}{$-0,327-0,127$} & & \multirow{5}{*}{0,375} \\
\hline & Kel. Kontrol & & & & \multirow{4}{*}{$-0,902$} & \\
\hline & Sebelum & 7,73 & 2,303 & & & \\
\hline & Sesudah & 7,83 & 2,052 & & & \\
\hline & Selisih & $-0,100$ & & & & \\
\hline Sikap dlm & Kel. Intervensi & & & \multirow{3}{*}{$-2,716--1,990$} & \multirow{3}{*}{$-13,179$} & \multirow{3}{*}{0,000} \\
\hline \multirow[t]{7}{*}{ Eksklusif } & Sebelum & 4,65 & 0,544 & & & \\
\hline & Sesudah & 7,00 & 0,953 & & & \\
\hline & Selisih & $-2,353$ & & \multirow{5}{*}{$-0,405-0,005$} & \multirow{5}{*}{$-1,989$} & \multirow{5}{*}{0,056} \\
\hline & Kel. Kontrol & & & & & \\
\hline & Sebelum & 3,86 & 0,819 & & & \\
\hline & Sesudah & 4,07 & 0,907 & & & \\
\hline & Selisih & $-0,20$ & & & & \\
\hline Perilaku dlm ASI & Kel. Intervensi I & & & \multirow{5}{*}{$-1,658--0,990$} & \multirow{4}{*}{$-8,043$} & \multirow{3}{*}{0,000} \\
\hline \multirow[t]{7}{*}{ Eksklusif } & Sebelum & 4,86 & 1,134 & & & \\
\hline & Sesudah & 6,19 & 1,023 & & & \\
\hline & Selisih & $-1,324$ & & & & \\
\hline & Kel. Kontrol & & & & \multirow{4}{*}{$-2,112$} & \multirow{4}{*}{0.063} \\
\hline & Sebelum & 5,53 & 2,224 & \multirow[t]{3}{*}{$-0,262--0,004$} & & \\
\hline & Sesudah & 5,67 & 2,106 & & & \\
\hline & Selisih & $-0,133$ & & & & \\
\hline
\end{tabular}

Hasil analisis menunjukkan bahwa terdapat peningkatan skor pengetahuan pada responden yang mendapat perlakuan dengan besarnya peningatan skor 2,514 pada nilai $\mathrm{t}=6,970$, peningkatan skor sikap pada responden yang mendapatkan perlakuan dengan besarnya peningkatan skor 2,353 pada nilai $\mathrm{t}=13,179$, peningkatan skor ketrampilan pada responden yang mendapat perlakuan dengan besarnya peningkatan skor 1,324 pada nilai $\mathrm{t}=8,043$. Sehingga dapat disimpulkan bahwa terdapat pengaruh signifikan intervensi program inovasi pendampingan pemberian ASI pada ibu paska persalinan pada p-value 0,000 terhadap peningkatan skor pengetahuan, sikap dan ketrampilan responden.Berdasarkan hasil penelitian ini pada kelompok kontrol bahwa tidak ada penurunan pengetahuan, sikap dan perilaku, peningkatan BB bayi, dan status pemberian ASI sebelum dan sesudah intervensi. Pada kelompok intervensi terdapat terdapat peningkatan yang bermakna antar skor pengetahuan, ketrampilan, sikap, peningkatan BB dan status pemberian ASI sebelum dan sesudah intervensi. 
Edukasi untuk ibu bertujuan untuk meningkatkan pengetahuan, kemampuan dalam menyusui, juga berpengaruh terhadap sikap dan tindakan positif pemeberian ASI. Pendidikan kesehatan bagi ibu menyusui dapat diberikan masa prenatal (sebelum melahirkan) dan post partum (sesudah melahirkan). Edukasi yang diberikan pada ibu dapat dilakukan dengan beberapa cara yaitu melalui demonstrasi praktik menggunakan praktik menggunakan boneka dan video, atau dengan cara melalui melihat bagaimana menyusui yang benar pada bayi baru lahir, melalui pendampingan atau bimbingan kesehatan dalam proses menyusui merupakan pendidikan kesehatan lanjutan bagi ibu menyusui (Shealy, Li, BentonDavis \& Grummer-Strawn,2005).

Penelitian yang dilakukan oleh Rahayu (2007), memberikan hasil bahwa edukasi menyusui memberikan pengaruh yang baik terhadap pengetahuan ibu primipara tentang eksklusif dan tindakan dalam memberikan ASI, Sari (2009), melakukan penelitian hasil terdapat pengaruh yang signifikan penyuluhan kesehatan (pemberian leaflet) terhadap pengetahuan, sikap dan tindakan ibu dalam manajemen laktasi. Berdasarkan hasil penelitian ini pada kelompok kontrol bahwa tidak ada penurunan pengetahuan, sikap dan perilaku, peningkatan BB bayi, dan status pemberian ASI sebelum dan sesudah intervensi. Pada kelompok intervensi terdapat terdapat peningkatan yang bermakna antar skor pengetahuan, ketrampilan, sikap, peningkatan BB dan status pemberian ASI sebelum dan sesudah intervensi. Hasil penelitian ini disimpulkan bahwa proposi ibu yang memberikan makanan prelakteal sebanyak $76,0 \%$. Adapun faktor-faktor yang berhubungan dengan pemberian makanan prelakteal adalah tingkat pendidikan ibu, pengetahuan ibu, tradisi ibu dalam memberikan makanan prelakteal dan dukungan keluarga terhadap pemberian makanan prelakteal 
Tabel 4. Hasil analisa pemodelan Inovasi program pendampingan pemberian ASI pada ibu paska persalinan di RB Puskesmas Kecamatan Jatinegara, Cipayung, Matraman dan makasar (Mei - Juni $2016-\mathrm{N}=77$ responden)

\begin{tabular}{|c|c|c|c|c|c|c|}
\hline \multirow{2}{*}{\multicolumn{2}{|c|}{ Effect }} & \multirow{3}{*}{$\frac{\text { Value }}{.604}$} & \multicolumn{3}{|c|}{ Hypothesis } & \multirow{3}{*}{$\frac{\text { Sig. }}{.612}$} \\
\hline & & & $\mathrm{F}$ & $\mathrm{df}$ & Error df & \\
\hline \multirow[t]{3}{*}{ Usia } & $\begin{array}{l}\text { Skor Pengetahuan ASI } \\
\text { Eksklusif post Intervensi }\end{array}$ & & 1 & .604 & .271 & \\
\hline & $\begin{array}{l}\text { Skor Sikap thd ASI Eksklusif } \\
\text { post intervensi }\end{array}$ & .127 & 1 & .127 & .109 & .747 \\
\hline & $\begin{array}{l}\text { Skor Prilaku dlm ASI } \\
\text { Eksklusif post intervensi }\end{array}$ & .655 & 1 & .655 & .700 & .418 \\
\hline \multirow[t]{3}{*}{ Umurb } & $\begin{array}{l}\text { Skor Pengetahuan ASI } \\
\text { Eksklusif post Intervensi }\end{array}$ & 2.542 & 1 & 2.542 & 1.139 & .305 \\
\hline & $\begin{array}{l}\text { Skor Sikap thd ASI Eksklusif } \\
\text { post intervensi }\end{array}$ & .074 & 1 & .074 & .063 & .806 \\
\hline & $\begin{array}{l}\text { Skor Prilaku dlm ASI } \\
\text { Eksklusif post intervensi }\end{array}$ & .012 & 1 & .012 & .012 & .913 \\
\hline \multirow[t]{3}{*}{ Duksum } & $\begin{array}{l}\text { Skor Pengetahuan ASI } \\
\text { Eksklusif post Intervensi }\end{array}$ & .129 & 1 & .129 & .058 & .814 \\
\hline & $\begin{array}{l}\text { Skor Sikap thd ASI Eksklusif } \\
\text { post intervensi }\end{array}$ & .562 & 1 & .562 & .482 & .500 \\
\hline & $\begin{array}{l}\text { Skor Prilaku dlm ASI } \\
\text { Eksklusif post intervensi }\end{array}$ & 4.030 & 1 & 4.030 & 4.306 & .058 \\
\hline \multirow[t]{3}{*}{ KERJA1 } & $\begin{array}{l}\text { Skor Pengetahuan ASI } \\
\text { Eksklusif post Intervensi }\end{array}$ & .002 & 1 & .002 & .001 & .977 \\
\hline & $\begin{array}{l}\text { Skor Sikap thd ASI Eksklusif } \\
\text { post intervensi }\end{array}$ & .376 & 1 & .376 & .323 & .580 \\
\hline & $\begin{array}{l}\text { Skor Prilaku dlm ASI } \\
\text { Eksklusif post intervensi }\end{array}$ & .277 & 1 & .277 & .296 & .596 \\
\hline \multirow[t]{3}{*}{ Pdidik } & $\begin{array}{l}\text { Skor Pengetahuan ASI } \\
\text { Eksklusif post Intervensi }\end{array}$ & 6.374 & 1 & 6.374 & 2.857 & .115 \\
\hline & $\begin{array}{l}\text { Skor Sikap thd ASI Eksklusif } \\
\text { post intervensi }\end{array}$ & 1.171 & 1 & 1.171 & 1.003 & .335 \\
\hline & $\begin{array}{l}\text { Skor Prilaku dlm ASI } \\
\text { Eksklusif post intervensi }\end{array}$ & .051 & 1 & .051 & .054 & .819 \\
\hline \multirow[t]{3}{*}{ Status } & $\begin{array}{l}\text { Skor Pengetahuan ASI } \\
\text { Eksklusif post Intervensi }\end{array}$ & .641 & 1 & .641 & .287 & .601 \\
\hline & $\begin{array}{l}\text { Skor Sikap thd ASI Eksklusif } \\
\text { post intervensi }\end{array}$ & .006 & 1 & .006 & .005 & .942 \\
\hline & $\begin{array}{l}\text { Skor Prilaku dlm ASI } \\
\text { Eksklusif post intervensi }\end{array}$ & .006 & 1 & .006 & .007 & .935 \\
\hline
\end{tabular}

Hasil analisa multivariat menunjukan bahwa dari hasil penelitian Destriatania menyatakan bahwa Sikap ayah selama masa menyusui (nilai p \&lt; 0,05; OR = 
1,$\left.623 ; 95 \% \mathrm{CI}=1,086 \_2,425\right)$ merupakan faktor yang paling dominan memengaruhi praktik pemberian ASI eksklusif. Pengetahuan yang baik dan sikap yang positif diketahui sebagai faktor penting dalam keberhasilan praktik pemeberian ASI oleh ibu. Penelitian oleh Rima Melati (2015) ini bertujuan untuk mengetahui hubungan dukungan sosial suami dengan motivasi dalam menjaga kesehatan selama kehamilan. Bahwa ada hubungan yang sangat signifikan antara dukungan sosial suami dengan motivasi dalam menjaga kesehatan selama kehamilan. Semakin tinggi dukungan suami maka semakin tinggi motivasi menjaga kesehatan pada ibu hamil. Menurut Fitrayeni (2015) Hasil penelitian menunjukkan bahwa keinginan memiliki anak sangat diperngaruhi oleh dukungan suami. Dukungan suami merupakan faktor yang paling berpengaruh terhadap unmet need.

Peran suami merupakan faktor penting untuk menurunkan angka unmet need pada WUS dengan HIV positif sehingga disarankan untuk dilakukan konseling kontrasepsi berpasangan. Dari ke tiga penelitian diatas dapat disimpulakn bahwa peran dukungan suami terhadap perilaku ibu dalam menyusui sangat dominan. $\mathrm{Ku}$ dan Chow (2010) mengidentifikasi, bahwa faktor yang sangat berpengaruh terhadap pemberian ASI adalah dukungan sosial keluarga. Malau (2010) dalam penelitiannya menyatakan bahwa dukungan suami terhadap istri yang menyusui adalah sebagian besar baik. Dukungan suami merupakan suatu upaya yangd ialkukan oleh suami baik secara moral maupun tindakan nyata yang diberikan pada istrinya untuk memberikan mitivasi dalam memberikan ASI pada bayinya. Dukungan suami sangat diperlukan oleh ibu dalam mengambil keputusan untuk memberikan ASI, ibu akan lebih termotivasi dan merasa percaya diri ketika menyusui. Kemasari (2008) menjelaskan bahwa dukungan suami pada istrinya yang menyusui berupa kemauan, kemampuan dan kesempatan, adalah hal yang sangat berperan untuk pengembalian keputusan dalam pemberian ASI.

Mengingat banyaknya faktor yang mempengaruhi keberhasilan dalam menyusui maka penelitian ini masih memiliki beberapa faktor yang merupakan keterbatasan seperti pendampingan pemberian ASI ini diberikan kepada ibu hanya dilaksanakan pada 2 x 30 menit, sehingga intervensi kurang berdampak secara langsung pada responden yang diteliti. Pendampingan memberikan ASI paska persalinan, hanya diberikan pada ibu tetapi tidak melibatkan suami sebagai pendukung utama karena hal ini akan dapat 
berpengaruh pada effektifitas pendampingan yang diberikan. Responden dalam penelitian ini adalah semua ibu menyusui, tidak mengambil ibu primipara saja atau multipara saja, dimungkinkan hasil penelitian kurang akurat.

\section{SIMPULAN}

Berdasarkan hasil penelitian yang telah diuraikan sebelumnya, dapat ditarik kesimpulan sebagai berikut:

1. Karakteristik responden pada kelompok intervensi sebagian besar responden berusia rata-rata 29,84 tahun, memiliki bayi berusia rata-rata 75,22 jam dan berlatar belakang pendidikan SMA (Sekolah Menengah Atas) dengan kepala keluarga (suami) memiliki pekerjaan wiraswasta, suami mendukung ASI Eksklusif dan ibu memberikan ASI eksklusif pada bayinya. Sedangkan pada kelompok kontrol sebagian besar berusia rata-rata 26,27 tahun, memiliki bayi berusia ratarata 39,3 jam dan berlatar belakang pendidikan SMA (Sekolah Menengah Atas) dengan kepala keluarga (suami) memiliki pekerjaan sebagai PNS atau karyawan swasta, suami kurang mendukung ASI Ekslusif dan ibu memberikan ASI Eksklusif pada bayinya.

2. Ada perbedaan pengetahuan, sikap dan perilaku ibu dalam memberikan ASI pada kelompok intervensi dan kelompok kontrol

3. Inovasi program pendampingan menyusi pada ibu paska persalinan berpengaruh terhadap terhadap peningkatan pengetahuan, sikap dan perilaku ibu dalam menyusui.

\section{DAFTAR RUJUKAN}

Azwar, A. 2000. Review Peningkatan Penggunaan ASI dan MP-ASI.

Depkes. 2007. Departement Of Health Human dan Services 2011.

Fitrayeni, F. 2013. Penyebab Rendahnya KelengkapanKunjungan Antenatal Care Ibu Hamil di Wilayah Kerja Puskesmas Pengambiran. Jurnal Kesehatan Masyarakat Andalas 9783833 (Print); 2442-6725 (Online)Publisher: Andalas University

Infodatin. 2013. Situasi dan Analisis ASI Eksklusif.(http://www.depkes.go.id/r esources/download/pusdatin/infodati $\mathrm{n} /$ info datin-asi

Kemenkes, 2013. Riset Kesehatan Dasar (Riskesdas) 2013. Badan Penelitian Dan Pengembangan Kesehatan : Kementerian Kesehatan RI

Kemenkes RI. 2009. Petunjuk Teknis Penggunaan Buku Kesehatan Ibu dan anak (KIA). Jakarta

Notoatmodjo, S. 2007. Penelitian Kesehatan Jakarta: Rineka

Notoatmodjo, S. 2014. Ilmu Perilaku Kesehatan. Jakarta: Rineka Cipta 
Lestari, S. 2012. Psikologi Keluarga. Jakarta: Kencana Prenada Media Group

Malau, A. 2010. Hubungan Dukungan Suami dan Kemauan Ibu Memberikan ASI Eksklusif di Puskesmas Teladan Medan.

Mercer, R.T. 2010. Becoming Mother verus Maternal Role Attainment. Jurnal of Nursing Scholarshipx, 226232.

Melati, R. 2012. Hubungan Dukungan Sosial Suami Dengan Motivasi Dalam Menjaga Kesehatan Selama Kehamilan. Jurnal Psikologi. ISSN:
1978-3655

(Print); 2407-8786

(Online) Publisher: Universitas Islam Negeri

Nursalam. 2008. Konsep \& penerapan metodologi penelitian ilmukeperawatan: pedoman skripsi, tesis,dan instrument penelitian keperawatan. Edisi 2 Jakarta: Salemba Medika

Russell, G., Hwang, C.P. 2004. The impact of workplace practices on father involvement In The role of the father in child development, Lamb, M.E. (Ed.), John Wiley: New Jersey; 476503

Roesli, U. 2007. Mengenal ASI Eksklusif. Jakarta: Trubus Agriwidya 